\title{
Molecular and cellular events during blastocyst implantation in the receptive uterus: clues from mouse models
}

\author{
Hiromichi MATSUMOTO', 2) \\ 1) Laboratory of Animal Breeding and Reproduction, Division of Animal Science, Department of Agrobiology and \\ Bioresources, School of Agriculture, Utsunomiya University, Tochigi 321-8505, Japan \\ ${ }^{2)}$ Center for Bioscience Research and Education, Utsunomiya University, Tochigi 321-8505, Japan
}

\begin{abstract}
The success of implantation is an interactive process between the blastocyst and the uterus. Synchronized development of embryos with uterine differentiation to a receptive state is necessary to complete pregnancy. The period of uterine receptivity for implantation is limited and referred to as the "implantation window", which is regulated by ovarian steroid hormones. Implantation process is complicated due to the many signaling molecules in the hierarchical mechanisms with the embryo-uterine dialogue. The mouse is widely used in animal research, and is uniquely suited for reproductive studies, i.e., having a large litter size and brief estrous cycles. This review first describes why the mouse is the preferred model for implantation studies, focusing on uterine morphology and physiological traits, and then highlights the knowledge on uterine receptivity and the hormonal regulation of blastocyst implantation in mice. Our recent study revealed that selective proteolysis in the activated blastocyst is associated with the completion of blastocyst implantation after embryo transfer. Furthermore, in the context of blastocyst implantation in the mouse, this review discusses the window of uterine receptivity, hormonal regulation, uterine vascular permeability and angiogenesis, the delayed-implantation mouse model, morphogens, adhesion molecules, crosslinker proteins, extracellular matrix, and matricellular proteins. A better understanding of uterine and blastocyst biology during the peri-implantation period should facilitate further development of reproductive technology. Key words: Blastocyst, Decidualization, Mouse, Steroid hormones, Uterine receptivity
\end{abstract}

(J. Reprod. Dev. 63: 445-454, 2017)

I mammalian reproduction, crosstalk between the blastocyst and the uterine luminal epithelium is essential for the implantation process $[1,2]$. The synchronization of embryonic development with uterine differentiation into a receptive state is essential for a successful pregnancy [1-13]. Uterine receptivity for implantation that supports blastocyst growth, attachment, and the subsequent events of implantation is time-limited. Implantation is a complex process involving spatiotemporally regulated endocrine, paracrine, autocrine, and juxtacrine modulators that mediate cell-cell and cell-matrix interactions [1-13]. The embryo is also an active unit with its own molecular program of cell growth and differentiation. The trophectoderm (TE) of implantation-competent blastocysts alters the embryo's functional programming via changes in cell surface molecules. The invasive trophoblasts of mouse blastocysts adhere, spread, and migrate on extracellular matrix (ECM) substrates [14-17] and penetrate three-dimensional ECM structures [18]. The proliferation and differentiation of uterine endometrial cells are also crucial steps during peri-implantation. Many molecules are involved in this process, including ECM, adhesion molecules, lipid mediators, and transcription factors. Successful embryo implantation is dependent

Received: March 31, 2017

Accepted: May 26, 2017

Published online in J-STAGE: June 22, 2017

(C)2017 by the Society for Reproduction and Development

Correspondence: H Matsumoto (e-mail: matsu@cc.utsunomiya-u.ac.jp)

This is an open-access article distributed under the terms of the Creative Commons Attribution Non-Commercial No Derivatives (by-nc-nd) License. (CC-BY-NC-ND 4.0: https://creativecommons.org/licenses/by-nc-nd/4.0/) on the cellular and molecular crosstalk between the uterus and the embryo; however, elucidation of the underlying molecular pathways has been hindered by their intricacy. The present review focuses on the molecular and cellular events during blastocyst implantation in the receptive uterus in a mouse model. This review first describes why the mouse is the preferred model organism for implantation studies, focusing on uterine morphology and physiological traits (Fig. 1), and then highlights knowledge regarding steroid hormonal regulation for blastocyst implantation and uterine receptivity (Fig. 2A). This review also describes the determinants of blastocyst competency and postimplantation development, i.e., selective proteolysis, adhesion molecules, crosslinker proteins, ECM, and matricellular proteins (Fig. 2B). Furthermore, this review describes the determinants of uterine receptivity and postimplantation uterine function, including morphogens, prostaglandins, and angiogenic factors (Fig. 2C).

\section{Mouse as the Preferred Model for Implantation Studies}

The mouse, Mus musculus, is widely used in animal research because of its small size, resistance to infection, relatively rapid generation time, and large litter size [19]. Furthermore, it is uniquely suited for reproductive studies, i.e., the sexual maturity of female mice begins around 6 weeks of age and vaginal cytology shows estrous cycles of 4-5 days [19].

The morphology of the female reproductive tract organs is markedly different among mammalian species, i.e., the mouse has a long duplex uterus with a dual cervix [20-23]. The duplex uterus in the 

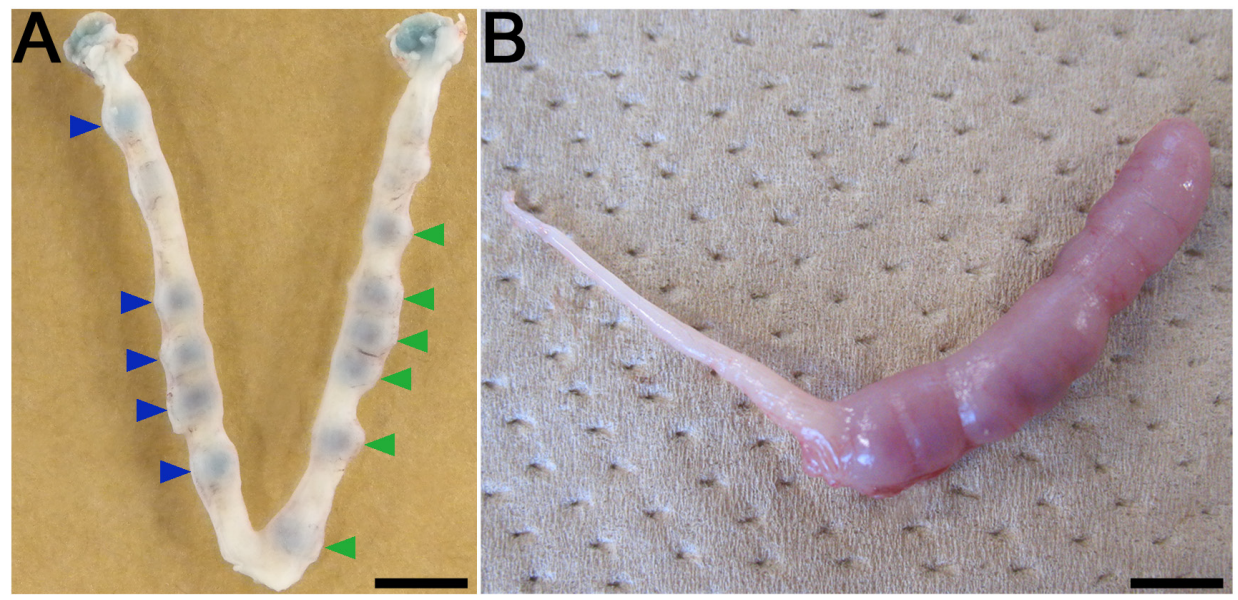

Fig. 1. The mouse uterus traits and the research paradigm for embryonic development and decidualization of uterine cells. (A) Implantation sites of transferred embryos and the uterine blue reaction 2 days after transference of blastocysts on day 6 of pregnancy (vaginal plug = day 1). Untreated control or treated blastocysts were transferred into one (left) or the other uterine horn (right) respectively. Mice have a long duplex uterus and it does not permit transuterine migration of embryos from one horn to the other. This trait allows the study of embryonic potential during the peri-implantation period for embryos transferred to the same recipient. Blue arrowheads and green arrowheads indicate the implantation sites of untreated control and treated embryos respectively. (B) Induced decidualization by artificial stimulus. Infusion of oil resulted in the decidual cell reaction (deciduoma). Pseudopregnant mice were given an intraluminal oil infusion ( $25 \mu 1)$ into one uterine horn (right) on day 4 to induce decidualization, followed by estimation on day 8 . The induction of uterine decidualization by artificial stimulus is useful to examine the effect of gene deficiency on uterine function and the steroidogenesis potential of transplanted ovarian tissues in ovariectomized mice. Scale bars represent $5 \mathrm{~mm}$.

mouse does not permit transuterine migration of embryos from one horn to the other, and this difference allows for maintenance of pregnancy in one uterine horn while the other horn does not contain embryos [20-22]. This trait is favorable for the study of the embryonic potential of transferred embryos during the peri-implantation period $[24,25]$, e.g., in the same recipient mouse, the untreated control or treated blastocysts are transferred into one or the other uterine horn, respectively, followed by comparison of the implantation rates (Fig. 1A)[24]. These physiological traits and experiment methodology allow the concurrent obtainment of both the implantation rate of the embryos and the pregnancy rate of the recipient mice.

In mice, blastocyst attachment stimulates the uterine stroma to form a spongy mass of cells known as decidual tissue. The process is known as the decidual reaction, and the mass of decidual cells around a single embryo can be referred as the deciduum or decidua [19]. The decidual reaction involves a rapid increase in the permeability of local capillaries, causing the uterine stroma to become swollen and edematous. The attachment reaction coincides with a localized increase in stromal vascular permeability at the site of the blastocyst, as can be demonstrated by intravenous injection of a macromolecular blue dye (the uterine blue reaction) (Fig. 1A) [26]. The first sign of the attachment reaction in the process of implantation (i.e., the apposition stage) occurs in the mouse towards the end of day 4 of the pregnancy (vaginal plug = day 1) $[26,27]$.

The decidual reaction only occurs in a uterus appropriately primed with progesterone and estrogen. Blastocysts are the normal inducers of these events, while various nonspecific stimuli, such as the intraluminal infusion of oil, air, and mechanical stimuli, can also initiate certain aspects of the decidual cell reaction (deciduoma) in pseudopregnant or steroid hormonally prepared uteri (Fig. 1B) [28]. Therefore, the induction of uterine decidualization by stimulus is used experimentally as a tool to examine the effect of gene deficiencies on uterine function $[1,2,29,30]$ and the potential for steroidogenesis in ovarian tissues transplanted into ovariectomized mice [31, 32].

\section{Ovarian Steroid Hormones Regulate Blastocyst Implantation and the "Window" of Uterine Receptivity}

For successful pregnancy in mice, uterine receptivity for implantation lasts for a limited time (Fig. 2A) [1, 4, 33, 34]. The duration of the receptive stage is also called the "implantation window". At this stage, the uterine environment is able to support blastocyst growth, attachment, and the subsequent implantation events. The ovarian steroids, progesterone $\left(\mathrm{P}_{4}\right)$ and $17 \beta$-estradiol $\left(\mathrm{E}_{2}\right)$, are crucial for implantation in mice (Fig. 2A) [35, 36]. The coordinated actions of $\mathrm{P}_{4}$ and $\mathrm{E}_{2}$, which regulate proliferation and/or differentiation of uterine cells in a spatiotemporal manner, establish the implantation window, i.e., on the first day of pregnancy in mice (as indicated by a vaginal plug); preovulatory $\mathrm{E}_{2}$ secretion induces the proliferation of uterine epithelial cells, and the increase in $\mathrm{P}_{4}$ levels secreted from the freshly formed corpora lutea initiates stromal cell proliferation from day 3 onward. [37]. The pre-receptive uterus on day 3 of pregnancy becomes receptive on day 4 due to rising $\mathrm{P}_{4}$ levels and a small elevation in ovarian $\mathrm{E}_{2}$ secretion (Fig. 2A) [36]. While $\mathrm{E}_{2}$ stimulates stromal cell proliferation, the coordinated effects of $\mathrm{P}_{4}$ and $\mathrm{E}_{2}$ halt uterine epithelial cell proliferation and initiate differentiation [37]. An active blastocyst in the uterus stimulates implantation during a 


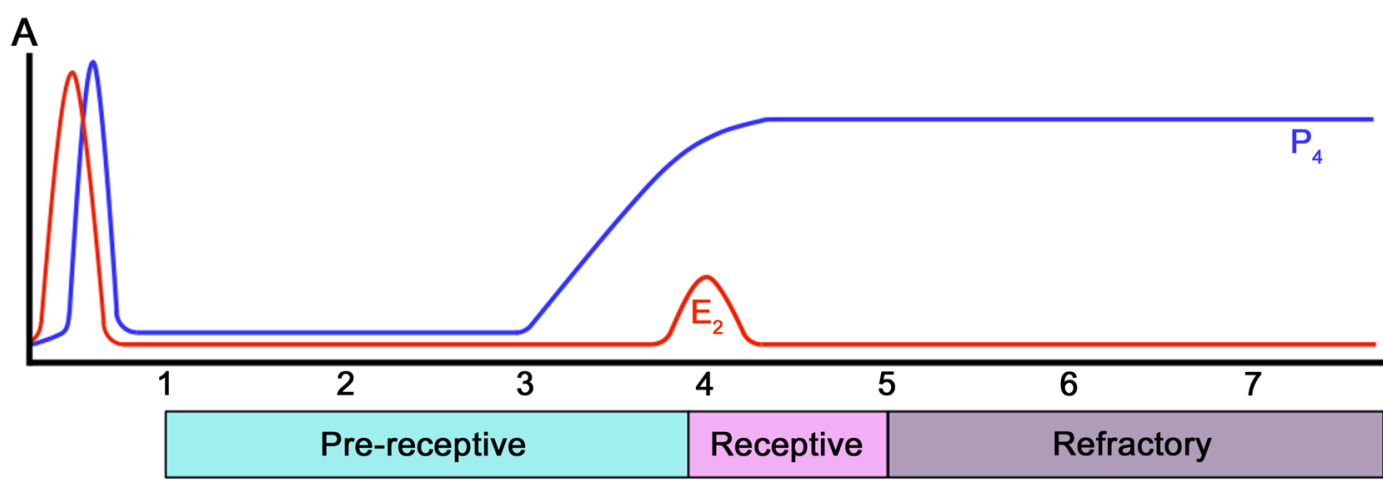

B

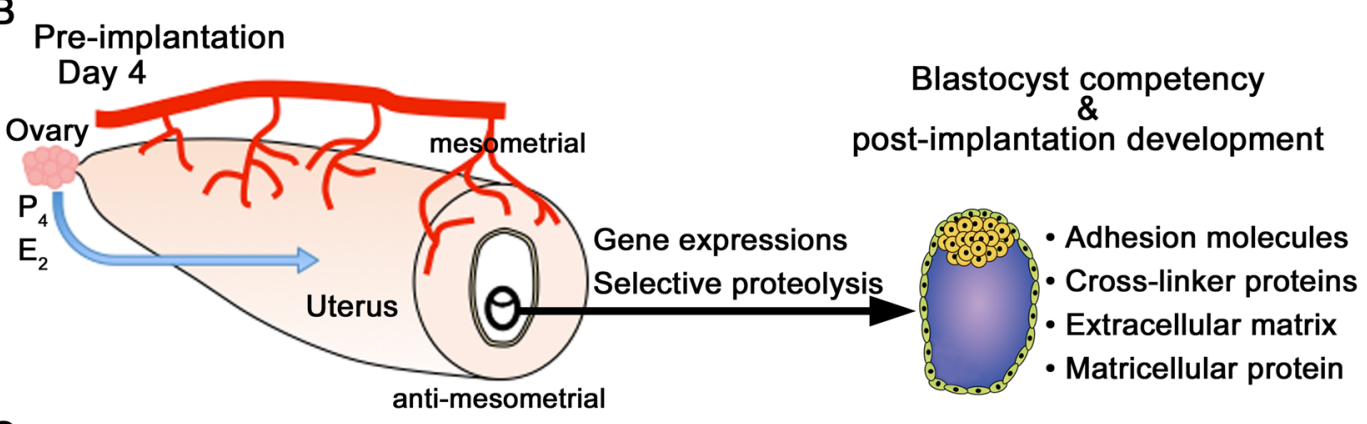

\section{C \\ Post-implantation
Day 7}

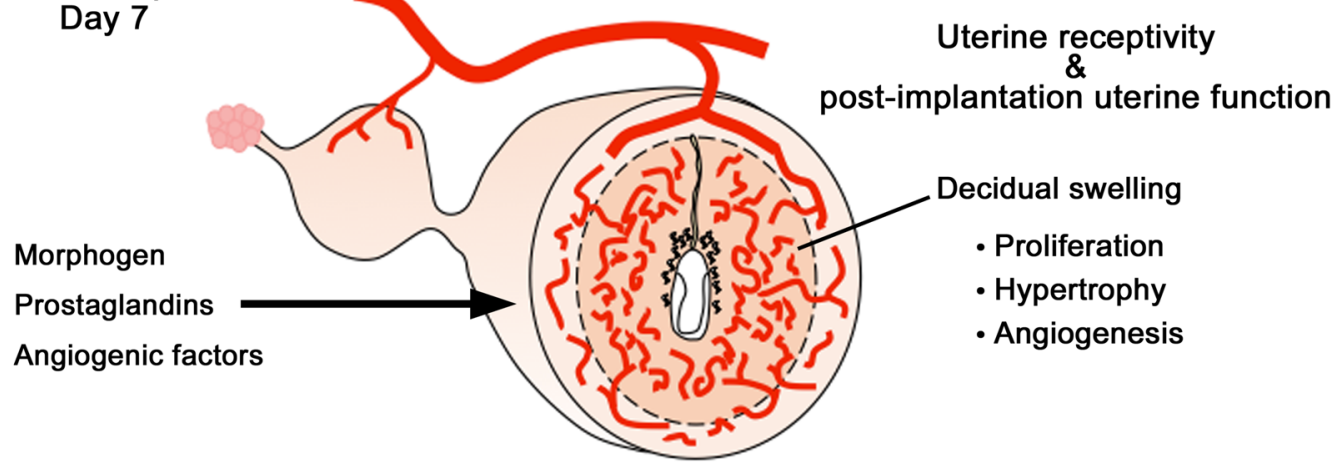

Fig. 2. Regulation of blastocyst implantation, uterine receptivity, and post-implantation development. (A) Regulation of the window for uterine receptivity is achieved by the actions of $\mathrm{P}_{4}$ and $\mathrm{E}_{2}$ in the mouse. Uterine sensitivity to implantation is categorized as pre-receptive, receptive, or refractory (nonreceptive) phases. The uterus is pre-receptive on days 1-3 of pregnancy or pseudopregnancy, it is receptive on day 4 , and by the afternoon of day 5 , it becomes refractory to implantation. The pre-receptive uterus on day 3 of pregnancy becomes receptive on day 4 due to rising $\mathrm{P}_{4}$ levels and a small elevation in ovarian $\mathrm{E}_{2}$ secretion. (B) Determinants of blastocyst competency and post-implantation development. This review also describes selective proteolysis, adhesion molecules, crosslinker proteins, extracellular matrix, and matricellular protein. (C) Determinants of uterine receptivity and post-implantation uterine function. This review also describes morphogens, prostaglandins, and angiogenic factors.

normal pregnancy. The first attachment reaction between the blastocyst TE and the uterine luminal epithelium occurs at the end of day 4 of pregnancy in the mouse. After attachment is initiated on day 4 at $2400 \mathrm{~h}$, the stromal cells surrounding the implanting blastocyst begin to proliferate extensively and differentiate into decidual cells (decidualization) $[1,4,9]$.

\section{$E_{2}$ is a Critical Determinant of the Duration of Uterine Receptivity for Implantation}

It has been demonstrated that within a very narrow range, the levels of $E_{2}$ determine the duration of the uterine receptivity window for embryo transfer [38]. Although $\mathrm{E}_{2}$ at different physiological concentrations can initiate implantation, the window of uterine receptivity remains open for an extended period at lower $\mathrm{E}_{2}$ levels, but rapidly closes at higher levels [38]. The uterine refractoriness that follows the receptive state at high $\mathrm{E}_{2}$ levels is accompanied by the aberrant expression of implantation-related genes. Therefore, the careful regulation of $E_{2}$ levels is an important factor for the improvement of female fertility in in vitro fertilization (IVF) and embryo transfer programs.

In contrast, these results suggest that the poor potential of ovar- 


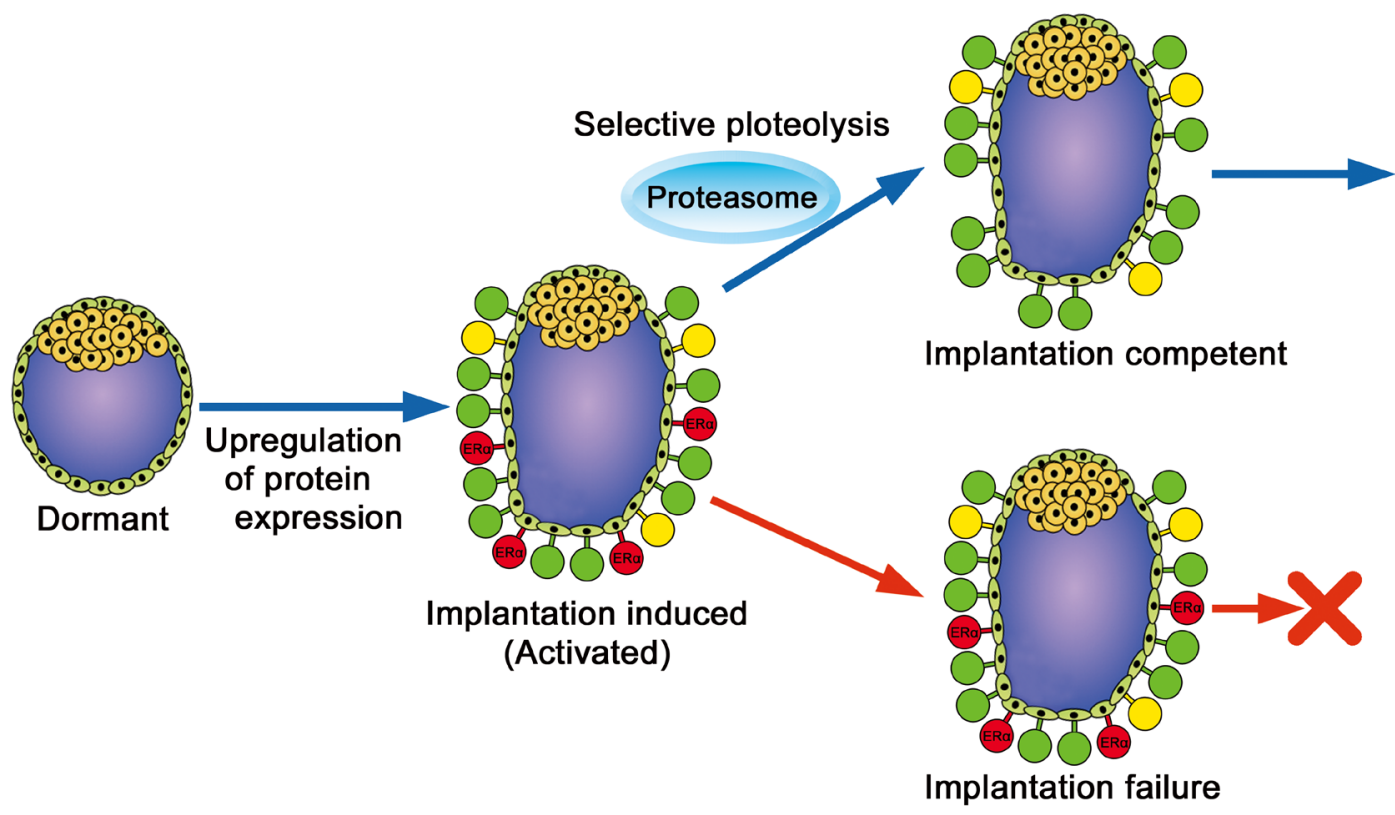

Fig. 3. A schematic diagram of blastocyst implantation competency. Protein expression (green, yellow, and red) is upregulated in implantation-induced (activated) blastocysts. The downregulation of specific proteins (red) in the activated blastocyst is critical for successful implantation. For example, the degradation of ER $\alpha$ is required for blastocyst implantation. Expressed proteins in activated blastocysts are categorized into three groups, i.e., essential (green), expressed but unnecessary (yellow), and obligatorily downregulated (red) to complete blastocyst implantation.

ian steroidogenesis extends the "implantation window". As such, vitrified-warmed ovarian tissue autotransplantation (VOAT) into estrus cycle-ceased ovariectomized mice restored fertility and led to full-term fetal development for the transferred embryos, although steroidogenesis and blood vessel formation in the corpus luteum were less than those in intact mice [31]. Indeed, the rate of live births was similar between VOAT mice that received an embryo transfer on pseudopregnancy day 4 and those that received the transfer on day 5 , whereas intact mice that received an embryo transfer on day 5 failed to support pregnancy [32]. For embryo transfer on pseudopregnancy day 5, oocyte warming and IVF can be performed on the day after mating a female with a vasectomized male. If a plug positive female is not obtained, oocyte warming and IVF can be postponed. Therefore, embryo transfer on day 5 could be a useful method for mice with poor ovarian potential for the improvement of female fertility within IVF and embryo transfer programs [32].

\section{Determinants of Blastocyst Competency Using the Delayed-implantation Mouse Model}

Delayed implantation is a process in which implantation is postponed for a period of time. This causes the uterus to remain quiescent and an embryo in the blastocyst stage to become dormant. In mice, an ovariectomy early on day 4 (vaginal plug = day 1 ) prior to pre-implantation $\mathrm{E}_{2}$ secretion prevents implantation and initiates blastocyst dormancy within the uterine lumen [39]. The delayed implantation can be maintained by continuous $\mathrm{P}_{4}$ treatment, but can be terminated upon $\mathrm{E}_{2}$ injection leading to blastocyst activation and subsequent implantation in the uterus approximately $24 \mathrm{~h}$ later.
For successful implantation in the receptive uterus, the blastocyst must also attain implantation competency, where the activity of the blastocyst determines the window of implantation in the receptive uterus $[36,38]$. The delayed implantation model is a powerful tool for defining the molecular signaling components that direct blastocyst activation or dormancy.

An analysis of global gene expression in the delayed implantation model demonstrated that these two different blastocyst physiological states can be distinguished at the molecular level, and that the genes involved control the cell cycle, cell signaling, and energy metabolism (Fig. 2B) [40]. The study also revealed an upregulation of Hbegf expression, which encodes heparin-binding EGF-like growth factor (HBEGF), and the HBEGF receptors ERBB1 and ERBB4 in blastocysts [40-42]. Catecholoestrogens produced from primary estrogens in the uterus activate blastocysts [43]. Another lipid-signaling molecule that targets blastocysts is the endocannabinoid anandamide, where endocannabinoid signaling is crucial for implantation in mice [44-46]. Levels of uterine anandamide and blastocyst CB1 are coordinately downregulated with the attainment of uterine receptivity and blastocyst activation respectively, but are elevated in the nonreceptive uterus and dormant blastocyst [46-48]. Anandamide regulates blastocyst functions by differentially modulating mitogen-activated protein kinase (MAPK) signaling and $\mathrm{Ca}^{2+}$ channel activity via $\mathrm{CB} 1$ [48]. This is consistent with findings that the MAPK and phosphatidylinositol 3-kinase/ $\mathrm{Ca}^{2+}$ signaling cascades are crucial to blastocyst development and activation [49-52]. 


\section{Degradation of Estrogen Receptor $\alpha$ in Activated Blastocysts is Associated with Implantation}

Although estrogen receptor $\alpha(\mathrm{ER} \alpha, E s r l)$ protein is expressed in blastocysts, its targeted disruption does not affect embryonic development or implantation $[53,54]$. Therefore, the expression of $\mathrm{ER} \alpha$ in blastocysts is considered unnecessary for the peri-implantation period. In contrast, ER $\alpha$ overexpression results in a decreased number of implantation sites and litter size [55]. These results suggest the possibility of an optimum level of ER $\alpha$ downregulation in blastocyst implantation during the peri-implantation period. Indeed, increased expression of ER $\alpha$ protein in implantation-induced (activated) blastocysts was decreased within $6 \mathrm{~h}$ in culture, whereas the expression of other proteins such as breast cancer 1 (BRCA1) was maintained in the blastocysts during culture (Fig. 3) [24]. The selective degradation of $E R \alpha$ expression in activated blastocysts is regulated by the ubiquitin-proteasome pathway (Fig. 2B, 3). Furthermore, downregulation of ER $\alpha$ in the activated blastocyst is associated with the completion of blastocyst implantation [24]. Although the reason for selective proteolysis immediately after expression in activated blastocysts is unclear, elimination of transcription factors to avoid inadequate protein expression could be associated with implantation competent blastocysts.

\section{Adhesion Molecules and Crosslinker Proteins}

For the attachment phase of implantation, adhesive signaling systems are required, e.g., numerous glycoproteins and carbohydrate ligands and their receptors are expressed in the TE and luminal epithelium around the time of implantation (Fig. 2B) [56, 57]. CD44 is likely involved in peri-implantation interactions. It recognizes polyanionic glycans including hyaluronan and chondroitin sulfate [58]. Furthermore, CD44 integral membrane proteins crosslink with actin filaments via ezrin/radixin/moesin (ERM) proteins in the organization of cortical actin-based cytoskeletons, including microvilli formation [59]. Radixin (also known as RDX) and ezrin (also known as EZR) are involved in the cellular organization of the TE during blastocyst activation prior to implantation in the delayed implantation mouse model, and radixin is particularly involved in preparing the mural TE for implantation, the presumptive site of attachment with the luminal epithelium (Fig. 2B) [60]. In contrast, the ERM-associated adhesive molecules, CD44, CD43 (also known as SPN), ICAM1 and ICAM2, are present in the TE of dormant blastocysts. These findings suggest that in dormant blastocysts prior to activation, adhesive molecules associated with ERM proteins are already positioned in a cell-specific manner to interact with radixin and ezrin in activated blastocysts [60]. Thus, ERM proteins expressed on TE cell surfaces of implantation-induced blastocysts may act as crosslinkers between actin and adhesive molecules and change the cell polarization and/or differentiation for adhesion and attachment with the luminal epithelium.

\section{ECM and Matricellular Protein TINAGL1}

The blastocyst is composed of distinct cell types, i.e., the pluripotent inner cell mass (ICM) generates future cell lineages of the embryo proper, while the outer epithelial TE makes the first physical and physiological connection with the maternal uterus for implantation. The invasive trophoblasts of mouse blastocysts adhere, spread, and migrate on ECM substrates [14-17] and penetrate the threedimensional ECM structures [18]. The TE of the implantation-induced blastocyst alters its functional programming via changes in cell surface molecules. The basement membrane consists predominantly of laminins and collagens secreted by the TE and the parietal endoderm of the pre-implantation blastocysts (Fig. 2B) [61] that then enter the implantation stage [62]. The parietal endoderm arises from the ICM in the blastocyst as a result of differentiation events and produces large quantities of ECM proteins to form the Reichert's membrane, which separates the yolk cavity from the maternal tissue $[63,64]$. The Reichert's membrane contains laminin and collagen IV $[65,66]$.

In contrast to the ECM, extracellular matrix proteins that do not contribute directly to the formation of structural elements in vertebrates but serve to modulate cell-matrix interactions and cell function are categorized as matricellular proteins [67]. The mouse ortholog of the gene encoding tubulointerstitial nephritis antigen-like 1 (TINAGL1, also known as adrenocortical zonation factor 1 [AZ-1] or lipocalin 7) has been cloned from mouse adrenocortical cells and is tightly linked with the zonal differentiation of this cell type [68]. TINAGL1 is a matricellular protein that interacts with both structural matrix proteins and cell surface receptors [69]. On the basis of its colocalization and binding ability with laminin 1 and collagens, TINAGL1 was found to be a component of the basal lamina [69]. During the pre-implantation phase of mouse embryonic development, the expression of both Tinagl1 mRNA and TINAGL1 protein is increased just prior to implantation (Fig. 2B) [66, 70]. In blastocysts, TINAGL1 expression is localized to the TE after hatching from the zona pellucida and is restricted to the basement membrane at the surface of the blastocoele site of the TE just prior to luminal epithelium attachment $[66,70]$. In post-implantation embryos, TINAGL1 is an extraembryonic tissue-specific protein and interacts with laminin 1 in the Reichert's membrane. In the uterus, TINAGL1 is expressed in the basement membrane of luminal epithelial cells during the pre-implantation period. During post-implantation, TINAGL1 is markedly expressed in the decidual endometrium, including the uterine capillaries, and it associates with integrins $\alpha 5$ and $\beta 1$ in the decidualized uterine endometrium [71]. These findings suggest that it plays a physical and physiological role in embryo development and/or decidualization of the uterine endometrium during pregnancy. Indeed, TINAGL1 deficiency affects female mice and results in subfertility phenotypes [72]. In humans, TINAGL1 protein is downregulated in preeclamptic women [73]. Furthermore, the behavior of trophoblasts invading the uterus resembles that of metastatic tumor cells, and recent studies have revealed a novel role for TINAGL1 that is associated with metastasis in cancer cells [74, 75]. Therefore, Tinagll knockout mice would likely substantially contribute to revealing the role of TINAGL1 in reproductive functions and metastasis.

\section{IHH as a Progesterone-responsive Factor Mediating Epithelial-mesenchymal Interactions in the Uterus}

The importance of morphogens for uterine receptivity has been reported, including research on hedgehog $(\mathrm{HH})$, WNT, and bone- 


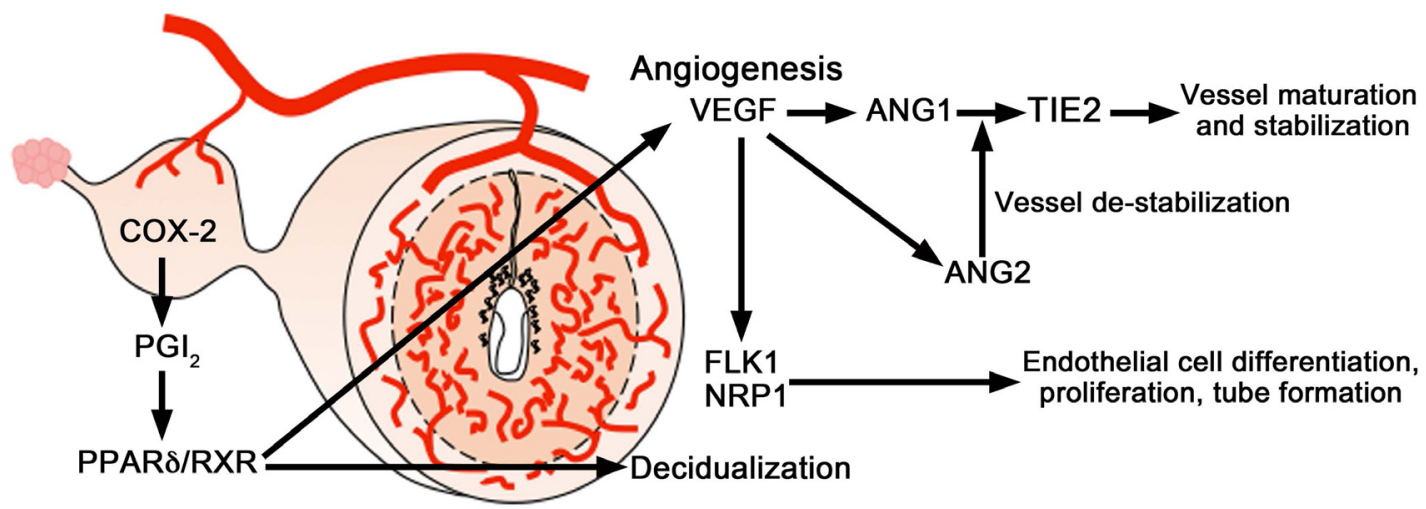

Fig. 4. A schematic diagram of angiogenic signaling in the uterus during implantation. COX2-derived prostaglandins are important for uterine angiogenesis during implantation and decidualization and primarily target the VEGF system, but not the angiopoietin system. The proangiogenic factor VEGF and its receptor FLK1 are important for uterine angiogenesis during the post-implantation period. VEGF in complementation with the angiopoietins (ANG1 and ANG2) and their receptor TIE2 directs angiogenesis during decidualization. ANG1 in collaboration with VEGF induces vessel maturation and maintains vessel leakiness, whereas ANG2 induces vessel destabilization required for further sprouting in the presence of VEGF.

morphogenetic-protein (BMP) signaling (Fig. 2C) [1, 2, 76]. Indian hedgehog $(I h h)$ expression is induced by $\mathrm{P}_{4}$ in the uterus [77-80]. The genes encoding the components of the HH signalling pathway, $\mathrm{Ihh}$, HH-binding protein/receptor Patched (Ptc) and the transcription factors Gli1-3 are expressed in the mouse uterus [77, 80]. Ihh expression is $\mathrm{P}_{4}$-dependent and reaches high levels in epithelial cells on day 4, while that of Ptc, Gli1 and Gli2 is upregulated in the underlying stroma [77]. In day 4 uterine-explant cultures, recombinant $\mathrm{N}$-sonic hedgehog $(\mathrm{N}-\mathrm{SHH})$ stimulates mesenchymal-cell proliferation, a characteristic of the receptive phase [77]. Furthermore, uterine deletion of $I h h$ leads to implantation failure due to poor uterine receptivity [78]. These results suggest that epithelial IHH functions as a paracrine growth factor for stromal cells and that this epithelial-mesenchymal signalling is important for uterine receptivity. The chicken ovalbumin upstream promoter-transcription factor II (COUP-TFII, Nr2f2) has been proposed as a downstream target of IHH signaling, and is expressed in the subepithelial stroma [81]. Uterine-specific COUPTFII knockout mice are infertile due to failure of implantation, i.e., epithelial IHH regulates stromal COUP-TFII to control BMP2 and regulate decidualization [81]. In addition, enhanced epithelial estrogen activity impedes the maturation of the receptive uterus in the absence of COUP-TFII [81]. These finding reveal that COUP-TFII plays a critical role in maintaining the balance between $\mathrm{E}_{2}$ and $\mathrm{P}_{4}$ activities to establish proper implantation.

\section{Uterine Angiogenesis via VEGF and Its Receptors}

The control of uterine angiogenesis by angiogenic factors, including vascular endothelial growth factor (VEGF) and its receptors, has been studied to assess its role in uterine angiogenesis during implantation and decidualization $[5,8,10]$. Differential splicing of the Vegf gene transcript generates several VEGF isoforms in both humans and mice. $\mathrm{VEGF}_{121}$ and $\mathrm{VEGF}_{165}$ are the predominant isoforms in humans, whereas $\mathrm{VEGF}_{120}$ and $\mathrm{VEGF}_{164}$ are the most predominant isoforms in mice $[82,83]$. In the mouse uterus, VEGF $_{164}$ mediates vascular changes and angiogenesis in the uterus during implantation and decidualization (Fig. 2C, 4)[83].

The effects of VEGF are primarily mediated by two tyrosine kinase receptors: VEGFR1 [fms-like tyrosine kinase 1(FLT1)] and VEGFR2 [fetal liver kinase 1 (FLK1)/kinase insert domain-containing receptor (KDR)] [84-87]. During the post-implantation period, the expression of Flk1 was evident in stromal cells close to, but not immediately surrounding, blastocysts on day 5 (Fig. 2, 4). On days 6-8 (Fig. 2, 4), Flk1 mRNA accumulation occurred in cells in both the mesometrial and anti-mesometrial decidual beds. However, Flk 1 expression was more intense at the mesometrial pole, the presumptive site of placentation and heightened angiogenesis. On day 8, some embryonic cells exhibited a marked accumulation of FlkI mRNA. Flk1 mRNA was absent from the avascular primary decidual zone (PDZ) [83, 88]. During peri-implantation in the mouse uterus, expression levels of Flt1, as detected by northern blot hybridization and in situ hybridization, were lower than those of Flk1 [88]. Another multifunctional VEGF receptor is neuropilin-1 (NRP1). The Nrp 1 mRNA expression pattern is similar to that of Flkl in the mouse uterus (Fig. 4) [83, 88]. However, it is interesting to note that Nrp1 mRNA was observed to be more widely distributed than Flk1, suggesting that NRP1 is present in stromal cells other than endothelial cells [83]. Collectively, genes encoding murine VEGF isoforms and their receptors, Flk1, Flt1, and Nrp1, are differentially expressed in the mouse uterus in a spatiotemporal manner during implantation, and the predominant $\mathrm{VEGF}_{164}$ isoform interacts with FLK1 and NRP1 $[83,88]$. These results suggest that the VEGF system is involved in uterine vascular permeability and angiogenesis during implantation (Fig. 4).

\section{Receptor TIE2 and Angiopoietins Substrates}

The effects of VEGF are complemented and coordinated by another class of angiogenic factors - the angiopoietins [89]. VEGF acts during the early stages of vessel development [90-92], while 
angiopoietin 1 (Ang1, also known as Angpt1) acts later to promote angiogenic remodeling, including vessel maturation, stabilization, and leakiness [93-95]. In contrast to the agonistic functions of ANG1, ANG2 behaves as an antagonist, i.e., ANG1 and ANG2 are naturally occurring positive and negative regulators of angiogenesis, respectively. They interact with an endothelial cell-specific tyrosine kinase receptor called TIE2 [96]. Collectively, VEGF and its receptor FLK1 are primarily important for uterine vascular permeability and angiogenesis before and during the attachment phase of implantation, whereas VEGF, together with the angiopoietins and their receptor TIE2, direct angiogenesis during decidualization after implantation (Fig. 4) [97].

\section{Prostaglandins Derived from COX2 Participate in Uterine Angiogenesis during Implantation and Decidualization}

Prostaglandins are also likely to participate in uterine vascular permeability and angiogenesis during implantation and decidualization, i.e., COX2 (also known as PTGS2)-derived prostaglandins participate in uterine angiogenesis during implantation and decidualization (Fig. 2C, 4) [97]. Cox2(-/-) mice show implantation and decidualization failure. The attenuation of uterine angiogenesis in these mice is primarily due to defects in VEGF signaling, rather than the angiopoietin system. Vegf $f_{164}$ expression is remarkably downregulated in stromal cells at the blastocyst site in $\operatorname{Cox} 2(-/-)$ mice. A prostacyclin $\left(\mathrm{PGI}_{2}\right)$ agonist, carbarprostacyclin (cPGI; a more stable analog of $\mathrm{PGI}_{2}$ ), functions as a ligand for peroxisome proliferator-activated receptor $\delta$ (PPAR $\delta$ ) and facilitates its heterodimerization with the retinoid $\mathrm{X}$ receptor (RXR). cPGI together with the RXR agonist, 9-cis-retinoic acid (9-cis-RA), improves the poor implantation in Cox2(-/-) mice [97, 98]. Administration of cPGI and 9-cis-RA also restored the expression of Vegf, as well as the number of blood vessels, leading to improved implantation. These results suggest COX2-derived prostaglandins influence uterine angiogenesis primarily by affecting the VEGF system during implantation (Fig. 4). In contrast, no significant difference was noted in the expression patterns of angiopoietins and Tie 2 between the Cox2(-/-) and wild type mice, although the decidual response was depressed in $\operatorname{Cox} 2(-/-)$ mice. Therefore, the angiopoietin signaling involved in uterine angiogenesis is distinct from that of the COX2-derived prostaglandins. Collectively, COX2derived prostaglandins direct angiogenesis during implantation and decidualization by differentially regulating VEGF and angiopoietin signaling (Fig. 2C, 4).

\section{Differential Regulation of $\mathrm{E}_{2}$ and $\mathrm{P}_{4}$ for Uterine Vascular Permeability and Angiogenesis}

The expression of VEGF and its receptors in the uterus is affected by steroid hormones [88]. $\mathrm{E}_{2}$ rapidly induces uterine vascular permeability and $\operatorname{Veg} f$ transcription through the nuclear estrogen receptor [88], and the Vegf gene contains estrogen response elements [99, 100]. $\mathrm{P}_{4}$ also upregulates uterine Vegf expression through activation of the nuclear progesterone receptor, but at a slower rate $[99,100] . \mathrm{E}_{2}$ was widely believed to be a potent stimulator of uterine angiogenesis during normal reproductive processes in vivo because vascular permeability is considered a prerequisite for angiogenesis and $\mathrm{E}_{2}$ rapidly stimulates uterine vascular permeability and Vegf expression. However, the evidence from molecular, genetic, physiological, and pharmacological studies has revealed that $\mathrm{E}_{2}$ and $\mathrm{P}_{4}$ have different effects in vivo. $\mathrm{E}_{2}$ promotes uterine vascular permeability but profoundly inhibits angiogenesis, whereas $\mathrm{P}_{4}$ stimulates angiogenesis with little effect on vascular permeability [101]. These effects of $E_{2}$ and $\mathrm{P}_{4}$ are mediated by the differential spatiotemporal expression of proangiogenic factors in the uterus [101].

\section{Differential Expression and Hormonal Regulation of Motin Family Members in the Uterus}

Angiomotin (AMOT) is a vascular angiogenesis-related protein that was initially identified as an angiogenesis inhibitor angiostatinbinding protein that can induce endothelial cell migration and tubule formation, and therefore, promote angiogenesis [102-104]. There are also two angiomotin-like proteins, AMOTL1 and AMOTL2. These three proteins belong to the motin family characterized by a highly conserved coil-coil domain, PDZ binding domain, and glutamine-rich domain [103]. AMOTL1 and AMOTL2 also play important roles in cell migration and angiogenesis [105-108]. The expression patterns of motin family members vary during development, i.e., there is a spatiotemporal-dependent expression of Amot, Amotl1, and Amotl2 in the mouse uterus during pre-implantation and post-implantation periods [109]. Specifically, ovarian steroid hormones regulate the differential expression of motins. The expression of Amot is induced by $\mathrm{P}_{4}$ in stromal cells. Amotll expression is upregulated by both $\mathrm{P}_{4}$ and $\mathrm{E}_{2}$ in stromal cells; however, $\mathrm{E}_{2}$ increases Amotll expression for only a limited time- $12 \mathrm{~h}$ after its expression diminishes. In contrast, $\mathrm{P}_{4}$ regulates the expression of Amotl2 in stromal cells while $\mathrm{E}_{2}$ regulates its expression in luminal epithelial cells. Collectively, Amot, Amotl1, and Amotl2 are differentially expressed in uterine cells during peri-implantation, and their expression is differentially regulated by $\mathrm{P}_{4}$ and $\mathrm{E}_{2}$.

\section{Conclusions}

Although many important discoveries have been made in this field, the knowledge of the complex events that occur during implantation is insufficient to prevent infertility caused by implantation failure. This review article describes the molecular and cellular events during blastocyst implantation in the receptive uterus in mouse models. These observations may help to elucidate the mechanisms underlying the completion of blastocyst implantation that allow for the establishment of pregnancy. The implantation rate of IVF-derived blastocysts after embryo transfer remains low, with poor embryo quality among the limiting factors for low pregnancy success in IVF. Therefore, it is possible that the inadequate expression of specific proteins in IVF-derived blastocysts induced by culture contributes to low implantation rates. In this instance, appropriate treatments to induce up- and/or down-regulation in vitro culture before embryo transfer may improve the implantation rate and embryonic development during the post-implantation period. However, further investigation is still required to develop strategies to further improve the success of implantation and pregnancy. 


\section{Acknowledgments}

I wish to thank all of my laboratory members and collaborators for their expert technical assistance and helpful discussions.

\section{References}

1. Wang H, Dey SK. Roadmap to embryo implantation: clues from mouse models. Nat Rev Genet 2006; 7: 185-199. [Medline] [CrossRef]

2. Cha J, Sun X, Dey SK. Mechanisms of implantation: strategies for successful pregnancy. Nat Med 2012; 18: 1754-1767. [Medline] [CrossRef]

3. Armant DR. Blastocysts dont go it alone. Extrinsic signals fine-tune the intrinsic developmental program of trophoblast cells. Dev Biol 2005; 280: 260-280. [Medline] [CrossRef]

4. Dey SK, Lim H, Das SK, Reese J, Paria BC, Daikoku T, Wang H. Molecular cues to implantation. Endocr Rev 2004; 25: 341-373. [Medline] [CrossRef]

5. Matsumoto H, Sato E. Uterine angiogenesis during implantation and decidualization in mice. Reprod Med Biol 2006; 5: 81-86.

6. Egashira M, Hirota Y. Uterine receptivity and embryo-uterine interactions in embryo implantation: lessons from mice. Reprod Med Biol 2013; 12: 127-132. [CrossRef]

7. Fritz R, Jain C, Armant DR. Cell signaling in trophoblast-uterine communication. Int J Dev Biol 2014; 58: 261-271. [Medline] [CrossRef]

8. Matsumoto H, Fukui E, Yoshizawa M. Uterine angiogenesis during implantation in mice. J Mamm Ova Res 2007; 24: 45-49. [CrossRef]

9. Matsumoto H, Fukui E, Yoshizawa M. Differential interactions between embryo and uterus during implantation in laboratory animals. J Mamm Ova Res 2009; 26: 111-115. [CrossRef]

10. Matsumoto H, Fukui E, Yoshizawa M. Angiogenesis and hormonal regulation on uterine receptivity for blastocyst implantation. J Mamm Ova Res 2015; 32: 79-85. [CrossRef]

11. Matsumoto H, Fukui E, Yoshizawa M. Molecular and cellular events involved in the completion of blastocyst implantation. Reprod Med Biol 2016; 15: 53-58. [CrossRef]

12. Yoshinaga K. Review of factors essential for blastocyst implantation for their modulating effects on the maternal immune system. Semin Cell Dev Biol 2008; 19: 161-169. [Medline] [CrossRef]

13. Yoshinaga K. Progesterone and its downstream molecules as blastocyst implantation essential factors. Am J Reprod Immunol 2014; 72: 117-128. [Medline] [CrossRef]

14. Armant DR, Kaplan HA, Lennarz WJ. Fibronectin and laminin promote in vitro attachment and outgrowth of mouse blastocysts. Dev Biol 1986; 116: 519-523. [Medline] [CrossRef]

15. Carson DD, Tang JP, Gay S. Collagens support embryo attachment and outgrowth in vitro: effects of the Arg-Gly-Asp sequence. Dev Biol 1988; 127: 368-375. [Medline] [CrossRef]

16. Sutherland AE, Calarco PG, Damsky CH. Expression and function of cell surface extracellular matrix receptors in mouse blastocyst attachment and outgrowth. $J$ Cell Biol 1988; 106: 1331-1348. [Medline] [CrossRef]

17. Yelian FD, Edgeworth NA, Dong LJ, Chung AE, Armant DR. Recombinant entactin promotes mouse primary trophoblast cell adhesion and migration through the Arg-GlyAsp (RGD) recognition sequence. J Cell Biol 1993; 121: 923-929. [Medline] [CrossRef]

18. Wordinger RJ, Brun-Zinkernagel AM, Jackson T. An ultrastructural study of in-vitro interaction of guinea-pig and mouse blastocysts with extracellular matrices. $J$ Reprod Fertil 1991; 93: 585-597. [Medline] [CrossRef]

19. Hogan B. R. B, Costantini F, Lacy E. Manipulating the mouse embryos: A laboratory manual. Cold Spring Harbor: Cold Spring Harbor Laboratory Press; 1994.

20. Johnson AD. Limitation of fetus number in the rat, mouse and rabbit. J Anim Sci 1970; 30: 978-983. [Medline] [CrossRef]

21. Clutter AC, Nielsen MK, Johnson RK. Alternative methods of selection for litter size in mice: I. Characterization of base population and development of methods. J Anim Sci 1990; 68: 3536-3542. [Medline] [CrossRef]

22. Clutter AC, Kirby YL, Nielsen MK. Uterine capacity and ovulation rate in mice selected 21 generations on alternative criteria to increase litter size. J Anim Sci 1994; 72: 577-583. [Medline]

23. Spencer TE, Dunlap KA, Filant J. Comparative developmental biology of the uterus: insights into mechanisms and developmental disruption. Mol Cell Endocrinol 2012; 354: 34-53. [Medline] [CrossRef]

24. Saito K, Furukawa E, Kobayashi M, Fukui E, Yoshizawa M, Matsumoto H. Degradation of estrogen receptor $\alpha$ in activated blastocysts is associated with implantation in the delayed implantation mouse model. Mol Hum Reprod 2014; 20: 384-391. [Medline] [CrossRef]

25. Li SJ, Wang TS, Qin FN, Huang Z, Liang XH, Gao F, Song Z, Yang ZM. Differential regulation of receptivity in two uterine horns of a recipient mouse following asynchronous embryo transfer. Sci Rep 2015; 5: 15897. [Medline] [CrossRef]

26. Psychoyos A. Endocrine control of egg implantation. In: Greep RO, Astwood EG, d Geiger SR (eds.), Handbook of physiology. Washington, DC: American Physiology Society; 1973: 187-215

27. Das SK, Wang XN, Paria BC, Damm D, Abraham JA, Klagsbrun M, Andrews GK, Dey SK. Heparin-binding EGF-like growth factor gene is induced in the mouse uterus temporally by the blastocyst solely at the site of its apposition: a possible ligand for interaction with blastocyst EGF-receptor in implantation. Development 1994; 120: 1071-1083. [Medline]

28. Dey SK. Implantation. In: Adashi EY, Rock JA, d Rosenwaks Z (eds.), Reproductive endocrinology, surgery and technology. New York: Lippincott-Raven; 1996: 421-434.

29. Lim H, Paria BC, Das SK, Dinchuk JE, Langenbach R, Trzaskos JM, Dey SK Multiple female reproductive failures in cyclooxygenase 2-deficient mice. Cell 1997; 91 197-208. [Medline] [CrossRef]

30. Matsumoto H, Ma W, Smalley W, Trzaskos J, Breyer RM, Dey SK. Diversification of cyclooxygenase-2-derived prostaglandins in ovulation and implantation. Biol Reprod 2001; 64: 1557-1565. [Medline] [CrossRef]

31. Matsumoto H, Ezoe K, Mitsui A, Fukui E, Ochi M, Yoshizawa M. Vitrified-warmed ovarian tissue autotransplantation into ovariectomized mice restores sufficient ovarian function to support full-term pregnancy. Reprod Med Biol 2011; 10: 185-191. [CrossRef]

32. Matsumoto H, Ezoe K, Mitsui A, Fukui E, Ochi M, Yoshizawa M. Extended uterin receptivity for blastocyst implantation and full-term fetal development in mice with vitrified-warmed ovarian tissue autotransplantation. Reprod Med Biol 2012; 11: 123-128. [CrossRef]

33. Paria BC, Reese J, Das SK, Dey SK. Deciphering the cross-talk of implantation: advances and challenges. Science 2002; 296: 2185-2188. [Medline] [CrossRef]

34. Red-Horse K, Zhou Y, Genbacev O, Prakobphol A, Foulk R, McMaster M, Fisher SJ. Trophoblast differentiation during embryo implantation and formation of the maternalfetal interface. J Clin Invest 2004; 114: 744-754. [Medline] [CrossRef]

35. McCormack JT, Greenwald GS. Evidence for a preimplantation rise in oestradiol-17beta levels on day 4 of pregnancy in the mouse. J Reprod Fertil 1974; 41: 297-301. [Medline] [CrossRef]

36. Paria BC, Huet-Hudson YM, Dey SK. Blastocysts state of activity determines the window of implantation in the receptive mouse uterus. Proc Natl Acad Sci USA 1993; 90: 10159-10162. [Medline] [CrossRef]

37. Huet-Hudson YM, Andrews GK, Dey SK. Cell type-specific localization of c-myc protein in the mouse uterus: modulation by steroid hormones and analysis of the periimplantation period. Endocrinology 1989; 125: 1683-1690. [Medline] [CrossRef]

38. Ma WG, Song H, Das SK, Paria BC, Dey SK. Estrogen is a critical determinant that specifies the duration of the window of uterine receptivity for implantation. Proc Natl Acad Sci USA 2003; 100: 2963-2968. [Medline] [CrossRef]

39. Yoshinaga K, Adams CE. Delayed implantation in the spayed, progesterone treated adult mouse. J Reprod Fertil 1966; 12: 593-595. [Medline] [CrossRef]

40. Hamatani T, Daikoku T, Wang H, Matsumoto H, Carter MG, Ko MS, Dey SK. Global gene expression analysis identifies molecular pathways distinguishing blastocys dormancy and activation. Proc Natl Acad Sci USA 2004; 101: 10326-10331. [Medline] [CrossRef]

41. Paria BC, Das SK, Andrews GK, Dey SK. Expression of the epidermal growth facto receptor gene is regulated in mouse blastocysts during delayed implantation. Proc Nat Acad Sci USA 1993; 90: 55-59. [Medline] [CrossRef]

42. Raab G, Kover K, Paria BC, Dey SK, Ezzell RM, Klagsbrun M. Mouse preimplantation blastocysts adhere to cells expressing the transmembrane form of heparin-binding EGF-like growth factor. Development 1996; 122: 637-645. [Medline]

43. Paria BC, Lim H, Wang XN, Liehr J, Das SK, Dey SK. Coordination of differential effects of primary estrogen and catecholestrogen on two distinct targets mediates embryo implantation in the mouse. Endocrinology 1998; 139: 5235-5246. [Medline] [CrossRef]

44. Paria BC, Das SK, Dey SK. The preimplantation mouse embryo is a target for cannabinoid ligand-receptor signaling. Proc Natl Acad Sci USA 1995; 92: 9460-9464. [Medline] [CrossRef]

45. Wang H, Guo Y, Wang D, Kingsley PJ, Marnett LJ, Das SK, DuBois RN, Dey SK. Aberrant cannabinoid signaling impairs oviductal transport of embryos. Nat Med 2004; 10 1074-1080. [Medline] [CrossRef]

46. Guo Y, Wang H, Okamoto Y, Ueda N, Kingsley PJ, Marnett LJ, Schmid HH, Das SK, Dey SK. N-acylphosphatidylethanolamine-hydrolyzing phospholipase D is an importan determinant of uterine anandamide levels during implantation. $J$ Biol Chem 2005; 280 23429-23432. [Medline] [CrossRef]

47. Paria BC, Song H, Wang X, Schmid PC, Krebsbach RJ, Schmid HH, Bonner TI, Zimmer A, Dey SK. Dysregulated cannabinoid signaling disrupts uterine receptivity for embryo implantation. J Biol Chem 2001; 276: 20523-20528. [Medline] [CrossRef]

48. Wang H, Matsumoto H, Guo Y, Paria BC, Roberts RL, Dey SK. Differential G proteincoupled cannabinoid receptor signaling by anandamide directs blastocyst activation for implantation. Proc Natl Acad Sci USA 2003; 100: 14914-14919. [Medline] [CrossRef] 
49. Stachecki JJ, Armant DR. Transient release of calcium from inositol 1,4,5-trisphosphatespecific stores regulates mouse preimplantation development. Development 1996; 122: 2485-2496. [Medline]

50. Wang J, Mayernik L, Schultz JF, Armant DR. Acceleration of trophoblast differentiation by heparin-binding EGF-like growth factor is dependent on the stage-specific activation of calcium influx by ErbB receptors in developing mouse blastocysts. Development 2000; 127: 33-44. [Medline]

51. Wang Y, Wang F, Sun T, Trostinskaia A, Wygle D, Puscheck E, Rappolee DA. Entire mitogen activated protein kinase (MAPK) pathway is present in preimplantation mouse embryos. Dev Dyn 2004; 231: 72-87. [Medline] [CrossRef]

52. Riley JK, Carayannopoulos MO, Wyman AH, Chi M, Ratajczak CK, Moley KH. The $\mathrm{PI} 3 \mathrm{~K} /$ Akt pathway is present and functional in the preimplantation mouse embryo. Dev Biol 2005; 284: 377-386. [Medline] [CrossRef]

53. Lubahn DB, Moyer JS, Golding TS, Couse JF, Korach KS, Smithies O. Alteration of reproductive function but not prenatal sexual development after insertional disruption of the mouse estrogen receptor gene. Proc Natl Acad Sci USA 1993; 90: 11162-11166. [Medline] [CrossRef]

54. Schomberg DW, Couse JF, Mukherjee A, Lubahn DB, Sar M, Mayo KE, Korach KS. Targeted disruption of the estrogen receptor-alpha gene in female mice: characterization of ovarian responses and phenotype in the adult. Endocrinology 1999; 140: 2733-2744. [Medline] [CrossRef]

55. Tomic D, Frech MS, Babus JK, Symonds D, Furth PA, Koos RD, Flaws JA. Effects of ERalpha overexpression on female reproduction in mice. Reprod Toxicol 2007; 23: 317-325. [Medline] [CrossRef]

56. Aplin JD. Adhesion molecules in implantation. Rev Reprod 1997; 2: 84-93. [Medline] [CrossRef]

57. Aplin JD, Singh H. Bioinformatics and transcriptomics studies of early implantation. Ann N Y Acad Sci 2008; 1127: 116-120. [Medline] [CrossRef]

58. Toyama-Sorimachi N, Sorimachi H, Tobita Y, Kitamura F, Yagita H, Suzuki K, Miyasaka M. A novel ligand for CD44 is serglycin, a hematopoietic cell lineage-specific proteoglycan. Possible involvement in lymphoid cell adherence and activation. J Biol Chem 1995; 270: 7437-7444. [Medline] [CrossRef]

59. Yonemura S, Tsukita $\mathbf{S}$, Tsukita $\mathbf{S}$. Direct involvement of ezrin/radixin/moesin (ERM)binding membrane proteins in the organization of microvilli in collaboration with activated ERM proteins. J Cell Biol 1999; 145: 1497-1509. [Medline] [CrossRef]

60. Matsumoto H, Daikoku T, Wang H, Sato E, Dey SK. Differential expression of ezrin/radixin/moesin (ERM) and ERM-associated adhesion molecules in the blastocyst and uterus suggests their functions during implantation. Biol Reprod 2004; 70: 729-736. [Medline] [CrossRef]

61. Li S, Edgar D, Fässler R, Wadsworth W, Yurchenco PD. The role of laminin in embryonic cell polarization and tissue organization. Dev Cell 2003; 4: 613-624. [Medline] [CrossRef]

62. Bedzhov I, Zernicka-Goetz M. Self-organizing properties of mouse pluripotent cells initiate morphogenesis upon implantation. Cell 2014; 156: 1032-1044. [Medline] [CrossRef]

63. Salamat M, Miosge N, Herken R. Development of Reicherts membrane in the early mouse embryo. Anat Embryol (Berl) 1995; 192: 275-281. [Medline] [CrossRef]

64. Verheijen MH, Defize LH. Signals governing extraembryonic endoderm formation in the mouse: involvement of the type 1 parathyroid hormone-related peptide (PTHrP) receptor, p21Ras and cell adhesion molecules. Int J Dev Biol 1999; 43: 711-721. [Medline]

65. Blankenship TN, Given RL. Loss of laminin and type IV collagen in uterine luminal epithelial basement membranes during blastocyst implantation in the mouse. Anat Rec 1995; 243: 27-36. [Medline] [CrossRef]

66. Igarashi T, Tajiri Y, Sakurai M, Sato E, Li D, Mukai K, Suematsu M, Fukui E, Yoshizawa M, Matsumoto H. Tubulointerstitial nephritis antigen-like 1 is expressed in extraembryonic tissues and interacts with laminin 1 in the Reichert membrane at postimplantation in the mouse. Biol Reprod 2009; 81: 948-955. [Medline] [CrossRef]

67. Bornstein P, Sage EH. Matricellular proteins: extracellular modulators of cell function. Curr Opin Cell Biol 2002; 14: 608-616. [Medline] [CrossRef]

68. Mukai K, Mitani F, Nagasawa H, Suzuki R, Suzuki T, Suematsu M, Ishimura Y. An inverse correlation between expression of a preprocathepsin B-related protein with cysteine-rich sequences and steroid 11 beta -hydroxylase in adrenocortical cells. $J$ Biol Chem 2003; 278: 17084-17092. [Medline] [CrossRef]

69. Li D, Mukai K, Suzuki T, Suzuki R, Yamashita S, Mitani F, Suematsu M. Adrenocortical zonation factor 1 is a novel matricellular protein promoting integrin-mediated adhesion of adrenocortical and vascular smooth muscle cells. FEBS J 2007; 274: 2506-2522. [Medline] [CrossRef]

70. Sakurai M, Sato Y, Mukai K, Suematsu M, Fukui E, Yoshizawa M, Tanemura K, Hoshino Y, Matsumoto H, Sato E. Distribution of tubulointerstitial nephritis antigen-like 1 and structural matrix proteins in mouse embryos during preimplantation development in vivo and in vitro. Zygote 2014; 22: 259-265. [Medline] [CrossRef]

71. Tajiri Y, Igarashi T, Li D, Mukai K, Suematsu M, Fukui E, Yoshizawa M, Matsumoto
H. Tubulointerstitial nephritis antigen-like 1 is expressed in the uterus and binds with integrins in decidualized endometrium during postimplantation in mice. Biol Reprod 2010; 82: 263-270. [Medline] [CrossRef]

72. Takahashi A, Rahim A, Takeuchi M, Fukui E, Yoshizawa M, Mukai K, Suematsu M, Hasuwa H, Okabe M, Matsumoto H. Impaired female fertility in tubulointerstitial antigen-like 1-deficient mice. J Reprod Dev 2016; 62: 43-49. [Medline] [CrossRef]

73. Mary S, Kulkarni MJ, Mehendale SS, Joshi SR, Giri AP. Tubulointerstitial nephritis antigen-like 1 protein is downregulated in the placenta of pre-eclamptic women. Clin Proteomics 2017; 14: 8. [Medline] [CrossRef]

74. Korpal M, EIl BJ, Buffa FM, Ibrahim T, Blanco MA, Celià-Terrassa T, Mercatali L, Khan Z, Goodarzi H, Hua Y, Wei Y, Hu G, Garcia BA, Ragoussis J, Amadori D, Harris AL, Kang Y. Direct targeting of Sec23a by miR-200s influences cancer cel secretome and promotes metastatic colonization. Nat Med 2011; 17: 1101-1108. [Medline] [CrossRef]

75. Umeyama H, Iwadate M, Taguchi YH. TINAGL1 and B3GALNT1 are potential therapy target genes to suppress metastasis in non-small cell lung cancer. BMC Genomics 2014; 15(Suppl 9): S2. [Medline] [CrossRef]

76. Paria BC, Ma W, Tan J, Raja S, Das SK, Dey SK, Hogan BL. Cellular and molecular responses of the uterus to embryo implantation can be elicited by locally applied growth factors. Proc Natl Acad Sci USA 2001; 98: 1047-1052. [Medline] [CrossRef]

77. Matsumoto H, Zhao X, Das SK, Hogan BL, Dey SK. Indian hedgehog as a progesterone-responsive factor mediating epithelial-mesenchymal interactions in the mouse uterus. Dev Biol 2002; 245: 280-290. [Medline] [CrossRef]

78. Lee K, Jeong J, Kwak I, Yu CT, Lanske B, Soegiarto DW, Toftgard R, Tsai MJ, Tsai S, Lydon JP, DeMayo FJ. Indian hedgehog is a major mediator of progesterone signaling in the mouse uterus. Nat Genet 2006; 38: 1204-1209. [Medline] [CrossRef]

79. Franco HL, Rubel CA, Large MJ, Wetendorf M, Fernandez-Valdivia R, Jeong JW, Spencer TE, Behringer RR, Lydon JP, Demayo FJ. Epithelial progesterone receptor exhibits pleiotropic roles in uterine development and function. FASEB $J$ 2012; 26: 1218-1227. [Medline] [CrossRef]

80. Takamoto N, Zhao B, Tsai SY, DeMayo FJ. Identification of Indian hedgehog as a progesterone-responsive gene in the murine uterus. Mol Endocrinol 2002; 16: 2338-2348. [Medline] [CrossRef]

81. Kurihara I, Lee DK, Petit FG, Jeong J, Lee K, Lydon JP, DeMayo FJ, Tsai MJ, Tsai SY. COUP-TFII mediates progesterone regulation of uterine implantation by controlling ER activity. PLoS Genet 2007; 3: e102. [Medline] [CrossRef]

82. Tischer E, Mitchell R, Hartman T, Silva M, Gospodarowicz D, Fiddes JC, Abraham JA. The human gene for vascular endothelial growth factor. Multiple protein forms are encoded through alternative exon splicing. J Biol Chem 1991; 266: 11947-11954. [Medline]

83. Halder JB, Zhao X, Soker S, Paria BC, Klagsbrun M, Das SK, Dey SK. Differential expression of VEGF isoforms and $\operatorname{VEGF}(164)$-specific receptor neuropilin-1 in the mouse uterus suggests a role for $\operatorname{VEGF}(164)$ in vascular permeability and angiogenesis during implantation. Genesis 2000; 26: 213-224. [Medline] [CrossRef]

84. Shibuya M, Yamaguchi S, Yamane A, Ikeda T, Tojo A, Matsushime H, Sato M. Nucleotide sequence and expression of a novel human receptor-type tyrosine kinase gene (flt) closely related to the fms family. Oncogene 1990; 5: 519-524. [Medline]

85. Peters KG, De Vries C, Williams LT. Vascular endothelial growth factor receptor expression during embryogenesis and tissue repair suggests a role in endothelial differentiation and blood vessel growth. Proc Natl Acad Sci USA 1993; 90: 8915-8919. [Medline] [CrossRef]

86. Millauer B, Wizigmann-Voos S, Schnürch H, Martinez R, Møller NP, Risau W, Ullrich A. High affinity VEGF binding and developmental expression suggest Flk-1 as a major regulator of vasculogenesis and angiogenesis. Cell 1993; 72: 835-846. [Medline] [CrossRef]

87. Quinn TP, Peters KG, De Vries C, Ferrara N, Williams LT. Fetal liver kinase 1 is a receptor for vascular endothelial growth factor and is selectively expressed in vascular endothelium. Proc Natl Acad Sci USA 1993; 90: 7533-7537. [Medline] [CrossRef]

88. Chakraborty I, Das SK, Dey SK. Differential expression of vascular endothelial growth factor and its receptor mRNAs in the mouse uterus around the time of implantation. $J$ Endocrinol 1995; 147: 339-352. [Medline] [CrossRef]

89. Maisonpierre PC, Suri C, Jones PF, Bartunkova S, Wiegand SJ, Radziejewski C, Compton D, McClain J, Aldrich TH, Papadopoulos N, Daly TJ, Davis S, Sato TN, Yancopoulos GD. Angiopoietin-2, a natural antagonist for Tie2 that disrupts in vivo angiogenesis. Science 1997; 277: 55-60. [Medline] [CrossRef]

90. Carmeliet P, Ferreira V, Breier G, Pollefeyt S, Kieckens L, Gertsenstein M, Fahrig M, Vandenhoeck A, Harpal K, Eberhardt C, Declercq C, Pawling J, Moons L, Collen D, Risau W, Nagy A. Abnormal blood vessel development and lethality in embryos lacking a single VEGF allele. Nature 1996; 380: 435-439. [Medline] [CrossRef]

91. Ferrara N, Carver-Moore K, Chen H, Dowd M, Lu L, OShea KS, Powell-Braxton L, Hillan KJ, Moore MW. Heterozygous embryonic lethality induced by targeted inactivation of the VEGF gene. Nature 1996; 380: 439-442. [Medline] [CrossRef]

92. Shalaby F, Rossant J, Yamaguchi TP, Gertsenstein M, Wu XF, Breitman ML, Schuh 
AC. Failure of blood-island formation and vasculogenesis in Flk-1-deficient mice. Nature 1995; 376: 62-66. [Medline] [CrossRef]

93. Suri C, Jones PF, Patan S, Bartunkova S, Maisonpierre PC, Davis S, Sato TN, Yancopoulos GD. Requisite role of angiopoietin-1, a ligand for the TIE2 receptor, during embryonic angiogenesis. Cell 1996; 87: 1171-1180. [Medline] [CrossRef]

94. Thurston G, Suri C, Smith K, McClain J, Sato TN, Yancopoulos GD, McDonald DM. Leakage-resistant blood vessels in mice transgenically overexpressing angiopoietin-1. Science 1999; 286: 2511-2514. [Medline] [CrossRef]

95. Sato TN, Tozawa Y, Deutsch U, Wolburg-Buchholz K, Fujiwara Y, Gendron-Maguire M, Gridley T, Wolburg H, Risau W, Qin Y. Distinct roles of the receptor tyrosine kinases Tie-1 and Tie-2 in blood vessel formation. Nature 1995; 376: 70-74. [Medline] [CrossRef]

96. Davis S, Yancopoulos GD. The angiopoietins: Yin and Yang in angiogenesis. Curr Top Microbiol Immunol 1999; 237: 173-185. [Medline]

97. Matsumoto H, Ma WG, Daikoku T, Zhao X, Paria BC, Das SK, Trzaskos JM, Dey SK. Cyclooxygenase-2 differentially directs uterine angiogenesis during implantation in mice. J Biol Chem 2002; 277: 29260-29267. [Medline] [CrossRef]

98. Lim H, Gupta RA, Ma WG, Paria BC, Moller DE, Morrow JD, DuBois RN, Trzaskos JM, Dey SK. Cyclo-oxygenase-2-derived prostacyclin mediates embryo implantation in the mouse via PPARdelta. Genes Dev 1999; 13: 1561-1574. [Medline] [CrossRef]

99. Hyder SM, Stancel GM. Regulation of angiogenic growth factors in the female reproductive tract by estrogens and progestins. Mol Endocrinol 1999; 13: 806-811. [Medline] [CrossRef]

100. Hyder SM, Nawaz Z, Chiappetta C, Stancel GM. Identification of functional estrogen response elements in the gene coding for the potent angiogenic factor vascular endothelial growth factor. Cancer Res 2000; 60: 3183-3190. [Medline]

101. Ma W, Tan J, Matsumoto H, Robert B, Abrahamson DR, Das SK, Dey SK. Adult tissue angiogenesis: evidence for negative regulation by estrogen in the uterus. Mol Endo- crinol 2001; 15: 1983-1992. [Medline] [CrossRef]

102. Troyanovsky B, Levchenko T, Månsson G, Matvijenko O, Holmgren L. Angiomotin an angiostatin binding protein that regulates endothelial cell migration and tube formation. J Cell Biol 2001; 152: 1247-1254. [Medline] [CrossRef]

103. Bratt A, Wilson WJ, Troyanovsky B, Aase K, Kessler R, Van Meir EG, Holmgren L. Angiomotin belongs to a novel protein family with conserved coiled-coil and PDZ binding domains. Gene 2002; 298: 69-77. [Medline] [CrossRef]

104. Bratt A, Birot O, Sinha I, Veitonmäki N, Aase K, Ernkvist M, Holmgren L. Angiomotin regulates endothelial cell-cell junctions and cell motility. J Biol Chem 2005; 280: 34859-34869. [Medline] [CrossRef]

105. Gagné V, Moreau J, Plourde M, Lapointe M, Lord M, Gagnon E, Fernandes MJ. Human angiomotin-like 1 associates with an angiomotin protein complex through its coiledcoil domain and induces the remodeling of the actin cytoskeleton. Cell Motil Cytoskeleton 2009; 66: 754-768. [Medline] [CrossRef]

106. Huang H, Lu FI, Jia S, Meng S, Cao Y, Wang Y, Ma W, Yin K, Wen Z, Peng J, Thisse C, Thisse B, Meng A. Amot12 is essential for cell movements in zebrafish embryo an regulates c-Src translocation. Development 2007; 134: 979-988. [Medline] [CrossRef]

107. Zheng Y, Vertuani S, Nyström S, Audebert S, Meijer I, Tegnebratt T, Borg JP, Uhlén P, Majumdar A, Holmgren L. Angiomotin-like protein 1 controls endothelial polarity and junction stability during sprouting angiogenesis. Circ Res 2009; 105: 260-270. [Medline] [CrossRef]

108. Wang Y, Li Z, Xu P, Huang L, Tong J, Huang H, Meng A. Angiomotin-like2 gene (amotl2) is required for migration and proliferation of endothelial cells during angiogenesis. J Biol Chem 2011; 286: 41095-41104. [Medline] [CrossRef]

109. Matsumoto H, Fukui E, Yoshizawa M, Sato E, Daikoku T. Differential expression of the motin family in the peri-implantation mouse uterus and their hormonal regulation. $J$ Reprod Dev 2012; 58: 649-653. [Medline] [CrossRef] 